\title{
Induction of Glutamate Dehydrogenase in the Ovine Fetal Liver by Dexamethasone Infusion during Late Gestation ${ }^{1}$
}

\author{
M. Timmerman, * R.B. Wilkening $\dagger$, AND T.R.H. Regnault ${ }^{2} \dagger$ \\ *Department of Obstetrics and Gynecology, Erasmus University, Rotterdam, The Netherlands; and \\ $\uparrow$ Perinatal Research Center, Department of Pediatrics, Division of Perinatal Medicine, University of \\ Colorado Health Sciences Center, Aurora, CO 80010
}

Glucocorticoids near term are known to upregulate many important enzyme systems prior to birth. Glutamate dehydrogenase (GDH) is a mitochondrial enzyme that catalyzes both the reversible conversion of ammonium nitrogen into organic nitrogen (glutamate production) and the oxidative deamination of glutamate resulting in 2-oxoglutarate. The activity of this enzyme is considered to be of major importance in the development of catabolic conditions leading to gluconeogenesis prior to birth. Ovine hepatic GDH mRNA expression and activity were determined in near-term (130 days of gestation, term $147 \pm 4$ days) control and acutely dexamethasone-treated $\left(0.07 \mathrm{mg}^{-1}\right.$ $\mathrm{hr}^{-1}$ for $26 \mathrm{hr}$ ) fetuses. Dexamethasone infusion had no effect on placental or fetal liver weights. Dexamethasone infusion for $26 \mathrm{hr}$ significantly increased hepatic GDH mRNA expression. This increased GDH mRNA expression was accompanied by an increase in hepatic mitochondrial GDH activity, from $30.0 \pm 7.4$ to $58.2 \pm 8.1 \mathrm{U} \mathrm{GDH/U}$ CS (citrate synthase), and there was a significant correlation between GDH mRNA expression and GDH activity. The generated ovine GDH sequence displayed significant similarity with published human, rat, and murine GDH sequence. These data are consistent with the in vivo studies that have shown a redirection of glutamine carbon away from net hepatic glutamate release and into the citric acid cycle through the forward reaction catalyzed by GDH, i.e., glutamate to oxoglutarate. Exp Biol Med 228:100-105, 2003

Key words: glutamate dehydrogenase; fetal liver; dexamethasone; GDH activity

${ }^{1}$ This work was supported by the National Institutes of Health-National Institute of Child Health and Human Development (grant PO1 HD20761) and by the National Institutes of Health (grant IH RO1 HD 29374). A Fulbright Scholarship and the Ter Meulen Fund, Royal Dutch Academy of Arts and Sciences, supported M.T.

${ }^{2}$ To whom requests for reprints should be addressed at Department of Pediatrics, University of Colorado Health Sciences Center, Division of Perinatal Medicine, 13243 East 23rd Avenue, Aurora, CO 80010. E-mail: tim.regnault@uchsc.edu

Received June 10, 2002.

Accepted September 4, 2002

$1535-3702 / 03 / 2281-0100 \$ 15.00$

Copyright (C) 2003 by the Society for Experimental Biology and Medicine
7 he mitochondrial enzyme glutamate dehydrogenase (GDH; EC 2.1.14) catalyzes both the reversible conversion of ammonium nitrogen into organic nitrogen (glutamate production) and the oxidative deamination of glutamate, resulting in 2-oxoglutarate. The equilibrium of the enzyme favors the reverse reaction, the formation of glutamate under standard conditions $(1,2)$. This reverse reaction is the only pathway by which ammonia can become bound to the $\alpha$-carbon of a $\alpha$-carboxylic acid.

GDH activity has been documented for different physiological states, and in the myometrium, placenta, and fetal liver, brain, kidney, heart, and pancreas (3-11). The present study was stimulated by a number of studies directed at glutamine and glutamate exchange between the fetal liver and placenta $(12,13)$. These studies have shown that during ovine fetal life, glutamine, from maternal plasma, is transported across the placenta into the fetal circulation, from which it is taken up by the fetal liver in large quantities (14-16). The glutamine is used in part for net fetal glutamate release from the liver. The hepatic glutamate released maintains the fetal glutamate concentration and is the key determinant of glutamate delivery to the placenta. The placenta virtually clears all the glutamate from the fetal circulation, with an extraction coefficient of 75\%-90\% (12), and oxidizes it through the actions of placental GDH $(12,17)$. Recent studies have shown that a fetal dexamethasone infusion, sufficient to induce parturition, near term also causes a marked reduction in the net release of glutamate from the fetal liver. Using L- $\left[1-{ }^{13} \mathrm{C}\right]$ glutamine, it was shown that the glutamine carbon flux was redirected into the citric acid cycle, suggesting increased placental GDH activity under these conditions (13). The present study was designed to determine whether there was an increased expression of hepatic GDH mRNA and corresponding GDH activity after such a fetal dexamethasone infusion in the near-term ovine fetus.

\section{Material and Methods}

Animal Preparation. This study was approved by the University of Colorado Health Sciences Center Animal 
Care and Use Committee. Twelve time-mated 2- to 3-yearold Columbia-Rambouillet ewes pregnant with a single fetus were used. Surgery was performed to insert catheters for dexamethasone infusion at approximately 120 days of gestation (term $147 \pm 4$ days). Preoperatively, the ewe was given $500 \mathrm{mg}$ of ampicillin and $500 \mathrm{mg}$ of gentamycin intramuscularly. Surgery was performed under a combination of general pentobarbital $(65 \mathrm{mg} / \mathrm{ml})$ and spinal anesthesia ( $2 \mathrm{ml}$ of $1 \%$ pontocaine) after a 48 -hr fast with free access to water. During surgery, general anesthesia was maintained with intermittent i.v. infusion of pentobarbital via the jugular catheter. The fetus was anesthetized with pentobarbital via the maternal circulation. The uterus was exposed via a midline laparotomy incision. A 7- to 9-cm uterine incision was then made, a fetal forelimb was exteriorized, and an incision was made on the medial site of the knee joint. The brachial vein was located and a polyvinyl catheter (1.4 mm OD) was inserted. An amniotic catheter was also attached to the fetus by attachment to the brachial vein catheter for the injection of antibiotics into the amniotic cavity. The catheters were flushed every other day with heparinized saline $(30 \mathrm{U} / \mathrm{ml})$. At least 5 days were allowed for full recovery as assessed by normal $\mathrm{O}_{2}$ content and glucose concentration in the fetal circulation before dexamethasone infusion was commenced.

Experimental Design. On the day of study, at approximately 130 days of gestation, a bolus of $0.2 \mathrm{mg}$ of dexamethasone was administered to the fetus via the fetal brachial vein followed by a continuous infusion $\left(0.07 \mathrm{mg}^{-1}\right.$ $\mathrm{hr}^{-1}$ ) for $26 \mathrm{hr}$. This infusion rate and duration was based upon previous studies that concluded that this regime was sufficient to induce metabolic changes that were consistent with the onset of parturition (18). A group of five ewes comprised the control group. These animals had undergone fetal surgery for use in other studies, but problems with catheter patency made them unsuitable for their planned studies and thus available as controls in this study. After the experimental period, the fetus was delivered by cesarean section with i.v. pentobarbital anesthesia $(25 \mathrm{mg} / \mathrm{kg})$. The fetal liver was collected and weighed. The right lobe was removed and the left lobe was sectioned into slices after trimming the peripheral tissues. Approximately $10 \mathrm{~g}$ were placed in mitochondrial isolation medium (IM) buffer (220 $\mathrm{m} M$ mannitol, $70 \mathrm{~m} M$ sucrose, $2 \mathrm{~m} M$ Hepes, and $0.5 \mathrm{mg} / \mathrm{ml}$ bovine serum albumin [BSA], $\mathrm{pH} 7.4 ; 4^{\circ} \mathrm{C}$ ) for mitochondrial fraction isolation, which proceeded immediately. Mitochondria, for GDH activity determination, were obtained as previously described (19). Mitochondrial pellets were resuspended in $\mathrm{IM}$ buffer and were stored at $-80^{\circ} \mathrm{C}$. GDH activity was measured within 3 weeks of mitochondrial pellet preparation. The remaining liver slices were frozen in liquid nitrogen and were stored at $-80^{\circ} \mathrm{C}$ until later total cellular RNA extraction.

Enzymatic Analysis. The catalytic activity of GDH was determined at room temperature by measuring the decrease in absorbance due to the oxidation of NADH (20).
Briefly, mitochondrial samples were thawed on ice, diluted 1:1 with IM, sonicated, and centrifuged at $100,000 \mathrm{~g}$ for $1 \mathrm{hr}$ at $4^{\circ} \mathrm{C}$. The supernate was further diluted 1:20 with IM prior to assay. Ten to $50 \mu \mathrm{l}$ of diluted sample was added to a reaction mixture (64.5 $\mathrm{m} M$ TEA, $3.22 \mathrm{~m} M$ EDTA, $129 \mathrm{~m} M$ ammonium acetate, $\mathrm{pH}$ 8.0, $17.6 \mathrm{~m} M \mathrm{NADH}, 96 \mathrm{~m} M$ ADP, and $160 \mathrm{kU} / \mathrm{LDH}$ ). Absorbance was read at $339 \mathrm{~nm}$ until all endogenous pyruvate had been consumed. Once a steady state had been achieved, $100 \mu$ l of 2-oxoglutarate $(7 \mathrm{mM})$ was added and changes in absorbance (OD) were recorded every $30 \mathrm{sec}$ for up to $5 \mathrm{~min}$. Sample volumes that produced a linear decrease in absorbance no greater than $0.05 / \mathrm{min}$ over the 5-min oxidation period were used. NADH oxidation was linear with time and enzyme concentration under conditions reported in the original method (20). Samples were also assayed for citrate synthase (CS) activity as previously described (21). GDH activity was than expressed as units of GDH activity/units of CS activity, where a unit was defined as the change in OD per minute at $25^{\circ} \mathrm{C}$.

GDH Reverse Transcription-Polymerase Chain Reaction (RT-PCR). An ovine GDH cDNA probe was generated through RT-PCR. PCR primers were chosen based on published sequences of the human and rat GDH (X07769 and X14223, respectively): upper primer 5'-GCGAGGACGACCCCAACTT-3' and lower primer, 5'TCAATGCCAGGACCAATAA- $3^{\prime}$. The RT reaction was carried out using $1 \mu \mathrm{g}$ of ovine liver total cellular RNA (tcRNA) using SuperScriptII (Gibco-BRL, Gaithersburg, MD). Thermal cycling using Taq DNA polymerase included 35 cycles at $94^{\circ} \mathrm{C}$ for $1 \mathrm{~min}$, annealing at $60^{\circ} \mathrm{C}$ for 1 min, and extension at $72^{\circ} \mathrm{C}$ for an additional $1 \mathrm{~min}$. The PCR reaction was held at $72^{\circ} \mathrm{C}$ for a final extension for 10 min before being cooled to room temperature. An aliquot of the product was fractionated on a $1.5 \%$ agarose gel and was stained with ethidium bromide. Liver tcRNA samples yielded a single product of approximately 480 base pairs. After PCR, the product was cloned into pCR 2.1 (Invitrogen, Carlsbad, CA) and was then transformed using a INV $\alpha$ F' One Shot kit (Invitrogen).

Sequencing Data. Sequencing of the DNA was conducted on several clones using an ABI 377 automated DNA sequencer with dye rhodamine terminator chemistry using both the M13 Reverse and M13 forward primers. Nucleotide sequence verification was performed using basic local alignment search tool (BLAST; National Center for Biotechnology Information, Bethesda, MD). The amplified product sequenced corresponded to nucleotides 192-672 of human GDH (X07769) and was submitted to GenBank (accession number AY102935).

RNA Preparation and Northern Hybridizaion. Total cellular RNA was prepared using TRIREAGENT (Molecular Resource Center, Cincinnati, OH) as previously described (22). Total cellular RNA (20 $\mu \mathrm{g})$ was denatured and electrophoresed in a $1 \%$ agarose gel, glyoxal/DMSO in $0.01 \mathrm{MPO}_{4}$ buffer $(\mathrm{pH} 7.4)$ and was transferred to an $\mathrm{N}^{+}$Hybond membrane (Amersham, Pis- 
cataway, NJ) using a pressure blotter PosiBlot (Stratagene, La Jolla, CA) under alkaline conditions (10 $\mathrm{m} M \mathrm{NaOH})$. After transfer, membranes were UV crosslinked and rinsed in $6 \times \mathrm{SSC}\left(0.72 \mathrm{M} \mathrm{NaCl}, 40 \mathrm{mM} \mathrm{Na} \mathrm{HPO}_{4} .7 \mathrm{H}_{2} \mathrm{O}\right.$, and 4 $\mathrm{m} M$ EDTA) before the integrity of RNA and transfer efficacy was confirmed by methylene blue staining (23). The membranes were then rinsed in diethyl pyrocarbonatetreated water until the membrane was clear of background stain. These procedures were conducted at room temperature. Stained membranes were photographed, and samples not displaying distinct and clear $28 \mathrm{~S}$ and $18 \mathrm{~S}$ rRNA were discarded.

Transferred membranes were prehybridized $(6 \times \mathrm{SSC}$, $50 \%$ [v/v] formamide, $10 \%$ [w/v] sulfate Dextran, $7 \%$ [w/v] sodium dodecyl sulfate [SDS], $5 \mu \mathrm{g} / \mathrm{ml}$ denatured salmon sperm DNA, and $1005 \mu \mathrm{g} / \mathrm{ml}$ yeast tRNA (Gibco-BRL) for $2-4 \mathrm{hr}$ at $42^{\circ} \mathrm{C}$. Membranes were then hybridized with a 481 base pair EcoRI-EcoRI ${ }^{32} \mathrm{P}$-labeled ovine-specific GDH cDNA fragment at a concentration of $1-2 \times 10^{6} \mathrm{cpm} / \mathrm{ml}$. After a 16-hr hybridization period at $42^{\circ} \mathrm{C}$, membranes were washed twice with $2 \times \mathrm{SSC} / 0.1 \% \mathrm{SDS}$ for $20 \mathrm{~min}$ at room temperature and then twice with $0.1 \times \mathrm{SSC} / 0.1 \% \mathrm{SDS}$ for 15 min each at $65^{\circ} \mathrm{C}$. The molecular size of ovine GDHspecific band was estimated from a $0.4-$ to $9.5-\mathrm{kb}$ RNA ladder (Gibco-BRL). Each gel was run with a sample of postnatal lamb and maternal liver, which served as a positive control for GDH expression. Membranes were exposed to a phosphorus plate for $12 \mathrm{hr}$ and were scanned by a Storm system (Molecular Dynamics, Sunnyvale, CA). Resulting images were analyzed through ImageQuant (Molecular Dynamics) generating data in the form of mRNA expression volumes. To correct for loading and transfer differences after GDH quantification, the membranes were stripped ( $0.5 \%$ boiling SDS allowed to cool to room temperature) and reprobed with an 18s rRNA probe. 18s rRNA levels were measured by hybridization with an oligonucleotide probe (5'-ACGGTATCTGATCCGTCTTCGAACC-3') labeled with ${ }^{32} \mathrm{P}$-dCTP using terminal deoxytransferase (Boehringer Mannheim Biochemicals, Indianapolis, IN). After this, the membranes were subjected to the same washing procedures and image analysis as described.

Statistical Analysis. Gestational age and fetal and placental weights and values from the enzymatic analysis are reported as means \pm SEM. Results from the phosphorus imaging scanning, a ratio of ovine GDH mRNA expression compared wih 18s rRNA expression, are reported as means \pm SEM. Differences among groups were analyzed by Student's $t$ test with significance set at $P<0.05$.

\section{Results}

Tissue was collected at approximately 130 days of gestation after fetal treatment. A 26-hr dexamethasone infusion had no significant effects on fetal or fetal liver weights (Table I).

The nucleotide sequence of ovine cDNA for GDH is shown in Figure 1. The cDNA sequence for ovine GDH
Table I. Placenta and Fetal Parameters in Control, (5) and Dexamethasone, (7) Infused Fetus Near Term (130 Days of Gestation). Values are Mean \pm SEM

\begin{tabular}{lcc}
\hline & Control & Dexamethasone \\
\hline $\begin{array}{l}\text { Gestational } \\
\quad \text { age (days) }\end{array}$ & $130 \pm 2$ & $130 \pm 2$ \\
$\begin{array}{l}\text { Placental } \\
\text { weight }(\mathrm{g})\end{array}$ & $306.5(n=2)$ & $370.8 \pm 25.8(n=4)$ \\
Fetal weight $(\mathrm{g})$ & $2937.8 \pm 322.2$ & $3247.7 \pm 207.3$ \\
Fetal liver & & \\
$\quad$ weight $(\mathrm{g})$ & $116.8 \pm 11.0$ & $103.1 \pm 5.0$ \\
\hline
\end{tabular}

(GenBank Accession number AY102935) exhibits 95.2, 91.7, and 90.9\% homology with human (X07769, corresponding to bp 192-672), rat (X14223), and murine (X51081) sequences, respectively. In northern analysis, a single transcript of approximately $2.8 \mathrm{~kb}$ was displayed, which is in agreement with other published GDH message data (24).

Dexamethasone infusion for $26 \mathrm{hr}$ resulted in significantly elevated GDH mRNA expression $(P<0.02$; Fig. 2$)$. This increased GDH mRNA expression was accompanied by an increase in mitochondrial GDH activity from $30.0 \pm$ 7.4 to $58.2 \pm 8.1$ units of GDH activity/units of CS activity $(P<0.03$; Fig. 3). Moreover, there was a significant correlation between GDH mRNA expression and GDH activity $\left(P<0.001, \mathrm{r}^{2}=0.52\right.$; Fig. 4).

\section{Discussion}

These results demonstrate that under the influence of a fetal dexamethasone infusion near term, sufficient to induce parturition, the expression and activity of GDH in the fetal liver is increased. GDH is exclusively located in the mitochondrial matrix and catalyzes the reaction:

$$
\begin{gathered}
\text { glutamate }+\mathrm{NAD}^{+}+\mathrm{H}_{2} \mathrm{O} \leftrightarrows \\
\alpha \text {-ketoglutarate }+\mathrm{NH}_{4}+\mathrm{NADH}+\mathrm{H}^{+}
\end{gathered}
$$

The equilibrium coefficient of this reaction is $1 \sim 10 \times 10^{-14}$, which strongly favors glutamate production or what is termed the reverse reaction (2). Together with recently published data demonstrating that fetal dexamethasone infusion decreases fetal glutamate output (13), the results reported here demonstrate that the activity of GDH is increased and altered to favor the forward reaction, that is, the production of $\alpha$-ketoglutarate and associated reductive units. This dexamethasone-induced change in GDH activity could, in the normal course of events, be ascribed to the increased need for citric acid cycle intermediates for glycogen synthesis. In the fetal sheep, glucocorticoid infusions have been demonstrated to increase fetal liver glycogen concentrations (25), presumably through glucogenic enzymes such as GDH and cytosolic phosphoenolpyruvate carboxykinase, changes that occur naturally as parturition approaches.

The observation of increased hepatic GDH mRNA expression after fetal infusion of dexamethasone is the first 


\begin{tabular}{|c|c|c|c|c|}
\hline $\begin{array}{c}10 \\
\text { CTTCAAGATG }\end{array}$ & $\begin{array}{c}20 \\
\text { GTGGAGGGCT }\end{array}$ & $\begin{array}{c}30 \\
\text { TCTTTGACCG }\end{array}$ & $\begin{array}{c}40 \\
\text { CGGTGCCAGC }\end{array}$ & ATCGTGGAGG \\
\hline : : : : : : : : : & : : : : : : : : : : & $:::::$ & $::::::$ : & $::::$ \\
\hline $\begin{array}{r}\text { CTTCAAGATG } \\
305\end{array}$ & $\begin{array}{r}\text { GTGGAGGGCT } \\
315\end{array}$ & $\begin{array}{r}\text { TCTTCGATCG } \\
325\end{array}$ & $\begin{array}{r}\text { CGGCGCCAGC } \\
335\end{array}$ & $\begin{array}{r}\text { ATCGTGGAGG } \\
345\end{array}$ \\
\hline 60 & 70 & 80 & 90 & 100 \\
\hline ACAAGCTGGT & GGAGGACCTC & AAGACCCGGG & AGACCGAGGA & GCAGAAGCGG \\
\hline$:::::$ & $:::::::::$ & $:::::::::$ & $::: \quad::::::$ & $::::::::::$ : \\
\hline $\begin{array}{r}\text { ACAAGCTGGT } \\
355\end{array}$ & $\begin{array}{r}\text { GGAGGACCTG } \\
365\end{array}$ & $\begin{array}{r}\text { AGGACCCGGG } \\
375\end{array}$ & $\begin{array}{r}\text { AGAGCGAGGA } \\
385\end{array}$ & $\begin{array}{r}\text { GCAGAAGCGG } \\
395\end{array}$ \\
\hline 110 & 120 & 130 & 140 & 150 \\
\hline AACCGGGTGC & GTGGCATCCT & GCGGATCATC & AAGCCCTGCA & ACCATGTGCT \\
\hline $\begin{array}{r}::::::::::: \\
\text { AACCGGGTGC } \\
405\end{array}$ & $\begin{array}{r}: \quad::::::::: \\
\text { GCGGCATCCT } \\
415\end{array}$ & $\begin{array}{r}:::::::::: \\
\text { GCGGATCATC } \\
425\end{array}$ & $\begin{array}{r}:::::::::::: \\
\text { AAGCCCTGCA } \\
435\end{array}$ & $\begin{array}{r}::::::::::: \\
\text { ACCATGTGCT } \\
445\end{array}$ \\
\hline $\begin{array}{c}160 \\
\text { GAGCCTGTCC }\end{array}$ & $\begin{array}{r}170 \\
\text { TTCCCCATCC }\end{array}$ & $\begin{array}{c}180 \\
\text { GGCGCGACGA }\end{array}$ & $\begin{array}{r}190 \\
\text { CGGCTCCTGG }\end{array}$ & $\begin{array}{c}200 \\
\text { GAAGTCATTG }\end{array}$ \\
\hline $\begin{array}{c}::::: \quad::: \\
\text { GAGTCTCTCC } \\
455\end{array}$ & $\begin{array}{r}::::::::::: \\
\text { TTCCCCATCC } \\
465\end{array}$ & $\begin{array}{r}::::::::::: \\
\text { GGCGCGACGA } \\
475\end{array}$ & $\begin{array}{r}::::::::::: \\
\text { CGGCTCCTGG } \\
485\end{array}$ & $\begin{array}{r}:::::::: \\
\text { GAGGTCATCG } \\
495\end{array}$ \\
\hline 210 & 220 & 230 & 240 & 250 \\
\hline AGGGCTACCG & GGCCCAGCAC & AGCCAGCACC & GCACGCCCTG & CAAGGGAGGT \\
\hline $\begin{array}{r}: \quad:::::::::: \\
\text { AAGGCTACCG } \\
505\end{array}$ & $\begin{array}{r}:::::::::::: \\
\text { GGCCCAGCAC } \\
515\end{array}$ & $\begin{array}{r}:::::::::::: \\
\text { AGCCAGCACC } \\
525\end{array}$ & $\begin{array}{r}:::::::::::: \\
\text { GCACGCCCTG } \\
535\end{array}$ & $\begin{array}{r}::::::::::: \\
\text { CAAGGGAGGT } \\
545\end{array}$ \\
\hline 260 & 270 & 280 & 290 & 300 \\
\hline АTCCGTTACA & GCACCGATGT & GAGTGTAGAC & GAAGTTAAAG & СTCTGGCTTC \\
\hline $\begin{array}{r}::::::::::: \\
\text { ATCCGTTACA } \\
555\end{array}$ & $\begin{array}{r}:::: \quad::::: \\
\text { GCACTGATGT } \\
565\end{array}$ & $\begin{array}{c}::::::::: \\
\text { GAGTGTAGAT } \\
575\end{array}$ & $\begin{array}{r}::::::::: \\
\text { GAAGTAAAAG } \\
585\end{array}$ & $\begin{array}{r}::::::::: \\
\text { CTTTGGCTTC } \\
595\end{array}$ \\
\hline $\begin{array}{r}310 \\
\text { TCTGATGACG }\end{array}$ & 320 & 330 & 340 & 350 \\
\hline TCTGATGACG & TATAAGTGTG & CAGTGGT'TGA & TGTGCCATTT & GGGGGTGCCA \\
\hline $\begin{array}{r}\text { : : : : : : : : : } \\
\text { TCTGATGACA } \\
605\end{array}$ & $\begin{array}{r}::::::::: \\
\text { TACAAGTGTG } \\
615\end{array}$ & $\begin{array}{r}:::::::::: \\
\text { CAGTGGTTGA } \\
625\end{array}$ & $\begin{array}{r}:::::: \text { : : : } \\
\text { TGTGCCGTTT } \\
635\end{array}$ & $\begin{array}{r}\text { : : : : : : : : } \\
\text { GGGGGTGCTA } \\
645\end{array}$ \\
\hline 360 & 370 & 380 & 390 & $\$ 00$ \\
\hline AAGCTGGTGT & TAAGATCAAT & CCCAAGAACT & ATACTGATAA & CGAATTGGAA \\
\hline$::::::::::$ & $::::::::::$ & $::::::::::$ & : : : : : : : : : : & $:::::::::$ \\
\hline $\begin{array}{r}\text { AAGCTGGTGT } \\
655\end{array}$ & $\begin{array}{r}\text { TAAGATCAAT } \\
665\end{array}$ & $\begin{array}{r}\text { CCCAAGAACT } \\
675\end{array}$ & $\begin{array}{r}\text { ATACTGATAA } \\
685\end{array}$ & $\begin{array}{r}\text { TGAATTGGAA } \\
695\end{array}$ \\
\hline $\begin{array}{r}410 \\
\text { AGATCACAA }\end{array}$ & $\begin{array}{r}420 \\
\text { GGAGGTTCAC }\end{array}$ & $\begin{array}{c}430 \\
\text { CATGGAGCTG }\end{array}$ & $\begin{array}{r}440 \\
\text { GCAAAGAAGG }\end{array}$ & GCT \\
\hline $\begin{array}{c}:::::::::: \\
\text { AAGATCACAA } \\
705\end{array}$ & $\begin{array}{r}::::::::::: \\
\text { GGAGGTTCAC } \\
715\end{array}$ & $\begin{array}{l}::::::::: \\
\text { CATGGAGCTA } \\
725\end{array}$ & $\begin{array}{r}::::::::: \\
\text { GCAAAAAAGG } \\
735\end{array}$ & $\begin{array}{l}::: \\
\text { GCT }\end{array}$ \\
\hline
\end{tabular}

report of in utero alterations in liver enzymatic activity in the fetal sheep relative to glutamine/glutamate metabolism. Glucocorticoid-induced increases in hepatic GDH activity reported in this study are similar to those found previously in adult (4) and fetal $(3,9,24)$ rats, and the measured GDH activity nearly doubled in this study after the 26-hr dexa-
Figure 1. The sequence for sheep cDNA for glutamate dehydrogenase (GenBank accession number AY102935) aligned with the sequence for human GDH (M20867). methasone administration. In the rat, a relatively low activity of hepatic GDH has been described with activity increasing just prior to birth $(3,24)$, where an increase in glucocorticoid concentration would be expected. Moreover, maximal GDH mRNA expression levels are generally reached 2 days prior to birth, declining to prebirth levels, 


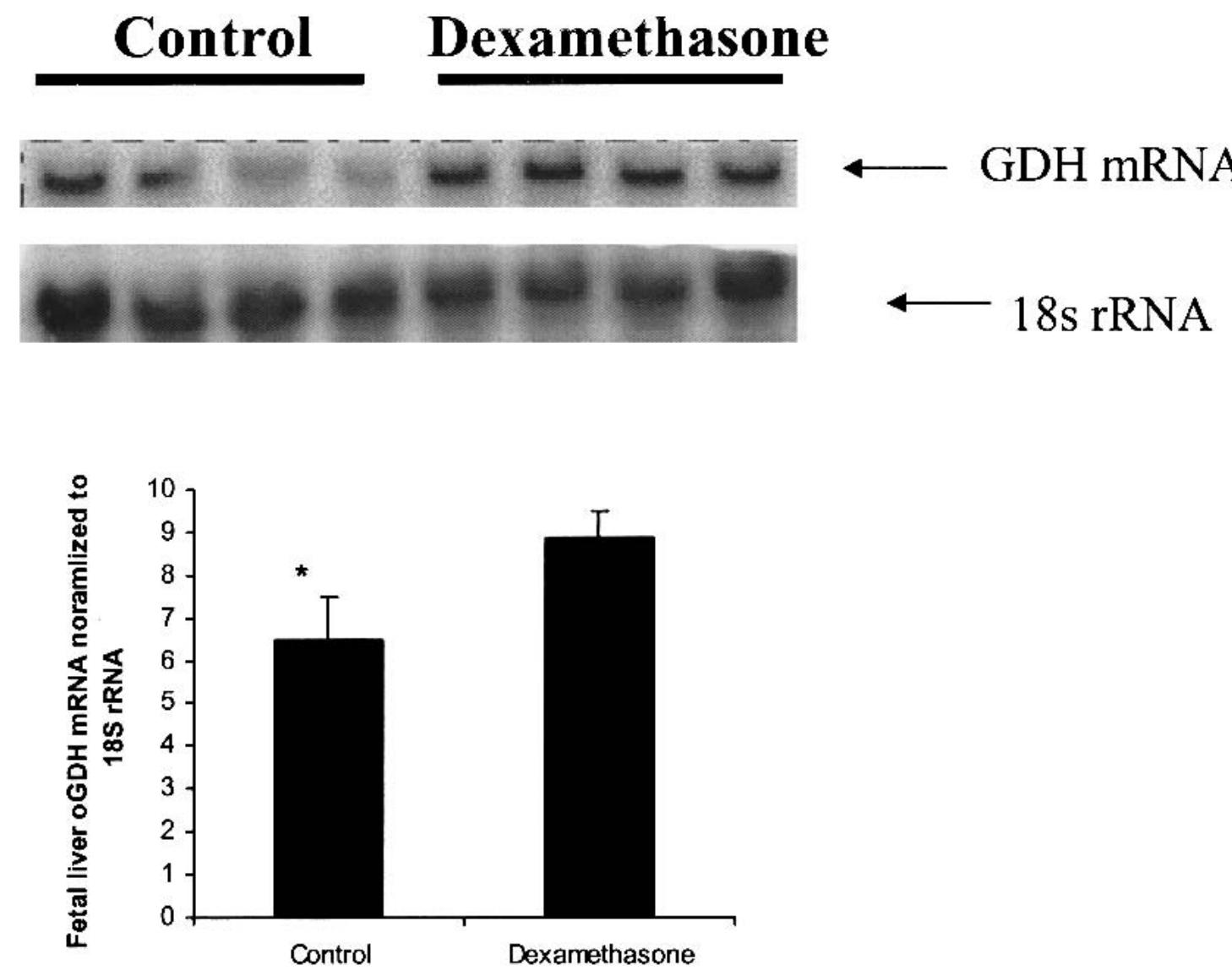

Figure 2. Northern blot analysis of oGDH mRNA fetal hepatic levels of control and dexamethasone-infused fetuses after $26 \mathrm{hr}$ of dexamethasone infusion. A single transcript was determined at approximately $2.8 \mathrm{~kb}$. Quantification of the oGDH mRNA levels normalized to the signal from $18 \mathrm{~s}$ mRNA is shown below. Values are means \pm SEM.

and then rising again to peak levels at 3-4 postnatal weeks (24). Of additional interest is the observation that in the rat placenta, as gestation advances, GDH activity actually decreases (9), suggesting a change in the placental metabolism of glutamate and placental production of ammonia. This change may occur as the placental role in fetoplacental

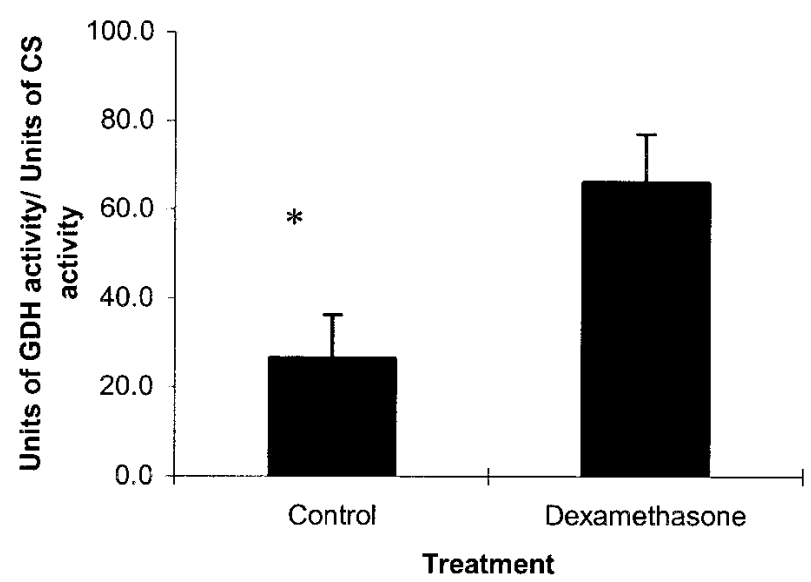

Figure 3. Hepatic GDH activity per citrate synthase activity for control and dexamethasone-treated fetuses after $26 \mathrm{hr}$ of dexamethasone infusion. Values are means \pm SEM. amino acid metabolism decreases and the fetus becomes the major regulator of fetoplacental amino acid metabolism. During the prenatal period, GDH mRNA expression is regulated at both the translational level as well as at the pretranslational level, whereas after birth, GDH expression is thought to be regulated predominantly at the pretranslational level (24). Studies in adult rats have shown that $\mathrm{T}_{3}$ treatment and cortisol increase the level of GDH, suggesting hormonal regulation of this gene (5). The induction of GDH activity by thyroid hormones is partly inhibited by blocking de novo protein synthesis, suggesting that $\mathrm{T}_{3}$ is involved in altering gene transcription as well as specific enzyme characteristics (5). During fetal life, regulation of GDH through thyroid hormone interactions have not yet been reported, though the branched chain amino acids, leucine, isoleucine, and valine are also reported to enhance GDH activity during fetal life (26).

In conclusion, we have demonstrated that infusion of dexamethasone induces significant increases in GDH message expression and GDH activity. These data are consistent with the in vivo studies, which have shown a redirection of glutamine carbon away from net hepatic glutamate release and into the citric acid cycle through the forward reaction catalyzed by GDH, i.e., glutamate to oxoglutarate. 


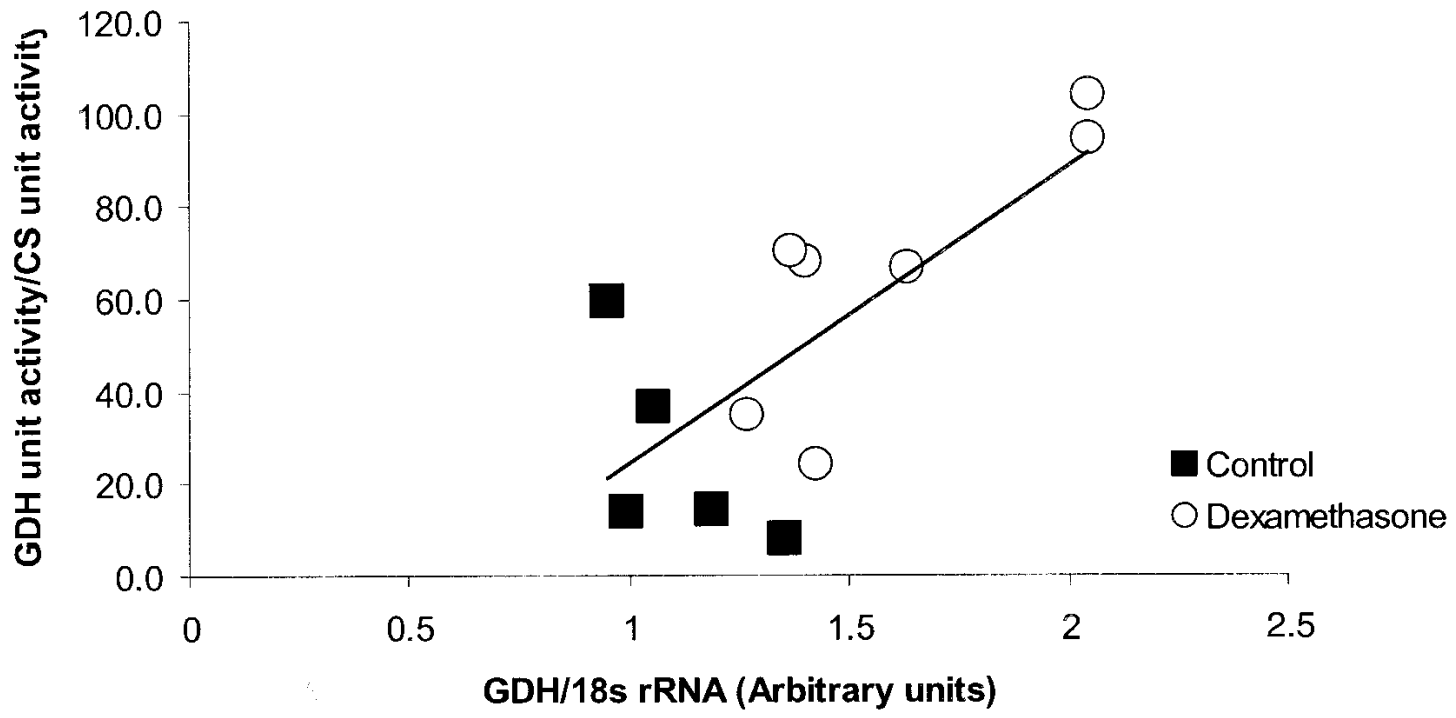

Figure 4. Relationship between hepatic GDH mRNA expression and activity in control and dexamethasone-treated fetuses after 26 hr of dexamethasone infusion. $Y=64.294 x-39.879, r^{2}=0.5223$. Values are means \pm SEM.

The authors thank Dr. Frederick C. Battaglia for his mentorship and guidance with this work, Dr. Russell V. Anthony for his assistance in primer design and RT-PCR troubleshooting, Meredith Davidsen for her technical assistance, and Susan Anderson, I-Da and Yu-Ching Fan, Willie Jones, Dave Hood, and Pete Orchard for their technical support and excellent care of the animals.

1. Smith EL, Austen B, Blumenthal KM, Nyc JF. Glutamate dehydrogenases. In: Boyle PD, Ed. The Enzymes (11th ed). New York: Academic Press, Vol 3:pp293-367, 1975.

2. Fisher HF. L-Glutamate dehydrogenase from bovine liver. Methods Enzymol 113:16-27, 1985.

3. Koppe P, Goetze E. Enzymatic activity of L-glutamic dehydrogenase in liver mitochondria of adult and fetal rats. Nature 211(51):887-888, 1966.

4. Nishikawara MT, Bricker JG. Relation between glucocorticoid level and hepatic glutamic dehydrogenase activity. Am J Physiol 210:586590, 1966

5. Yaroni S, Balinsky JB. Hormonal effects on liver glutamate dehydrogenase in adrenalectomized and thyroidectomized rats. Endocrinology 114:2337-2343, 1984.

6. Rolph TP, Jones CT, Parry D. Ultrastructural and enzymatic development of fetal guinea pig heart. Am J Physiol 243:H87-H93, 1982.

7. Jones CT, Ashton IK. The appearance, properties, and functions of gluconeogenic enzymes in the liver and kidney of the guinea pig during fetal and early neonatal development. Arch Biochem Biophys 174:506-522, 1976.

8. Geyer H, Riebschlager M. Effect of pregnancy on cytoplasmic and mitochondrial enzymes in human and animal myometrium. Acta Endocrinol 77:368-379, 1974.

9. Remesar X, Arola L, Palou A, Alemany M. Activities of enzymes involved in amino-acid metabolism in developing rat placenta. Eur $\mathbf{J}$ Biochem 110:289-293, 1980.

10. Rasschaert J, Malaisse WJ, Tanigawa K. Ontogeny of FAD-linked glycerophosphate dehydrogenase in rat pancreatic islets. Reprod Fertil Dev 8(3):443-448, 1996.

11. Leong SF, Clark JB. Regional development of glutamate dehydrogenase in the rat brain. J Neurochem 43:106-111, 1984.

12. Moores RR Jr., Vaughn PR, Battaglia FC, Fennessey PV, Wilkening $\mathrm{RB}$, Meschia G. Glutamate metabolism in fetus and placenta of lategestation sheep. Am J Physiol 267:R89-R96, 1994.

13. Timmerman M, Teng C, Wilkening RB, Fennessey P, Battaglia FC, Me- schia G. Effect of dexamethasone on fetal hepatic glutamine-glutamate exchange. Am J Physiol Endocrinol Metab 278:E839-E845, 2000.

14. Vaughn PR, Lobo C, Battaglia FC, Fennessey PV, Wilkening RB, Meschia G. Glutamine-glutamate exchange between placenta and fetal liver. Am J Physiol 268:E705-E711, 1995.

15. Chung M, Teng C, Timmerman M, Meschia G, Battaglia FC. Production and utilization of amino acids by ovine placenta in vivo. Am J Physiol 274:E13-E22, 1998.

16. Marconi AM, Battaglia FC, Meschia G, Sparks JW. A comparison of amino acid arteriovenous differences across the liver and placenta of the fetal lamb. Am J Physiol 257:E909-E915, 1989.

17. Pell JM, Jeacock MK, Shepherd DA. Interconversion of glutamate and glutamine in the placenta during development of foetal lambs. Proc Nutr Soc 38:19, 1979.

18. Barbera A, Wilkening RB, Teng C, Battaglia FC, Meschia G. Metabolic alterations in the fetal hepatic and umbilical circulations during glucocorticoid-induced parturition in sheep. Pediat Res 41:242-248, 1997.

19. Krebs JJ. The topology of phospholipids in artificial and biological membranes. J Bioenerg Biomembr 14:141-157, 1982.

20. Schmidt E, Schmidt FW. Oxidoreductases acting on groups other than $\mathrm{CHOH}$. In: Bergmeyer HU (Ed). Methods of Enzymatic Analysis (3rd ed). Weinheim Deerfield Beach: Verlag Chemie, Vol 3:pp216-27, 1983.

21. Shepherd D, Garland PB. The kinetic properties of citrate synthase from rat liver mitochondria. Biochem J 114:597-610, 1969.

21. Regnault TRH, Orbus RJ, de Vrijer B, Davidsen ML, Galan HL, Wilkening RB, Anthony RV. Placental expression of VEGF, PIGF and their receptors in a model of placental insufficiency-intrauterine growth restriction (PI-IUGR). Placenta 23:132-144, 2002.

22. Maniatis T, Fritsch EF, Sambrook J. Molecular Cloning: A Laboratory Manual. Cold Spring Harbor, NY: Cold Spring Harbor Laboratory Press, 1982.

23. Das AT, Salvado J, Boon L, Biharie G, Moorman AF, Lamers WH. Regulation of glutamate dehydrogenase expression in the developing rat liver: control at different levels in the prenatal period. Eur J Biochem 235(3):677-682, 1996.

24. Barnes RJ, Comline RS, Silver M. Effect of cortisol on liver glycogen concentrations in hypophysectomized, adrenalectomized and normal foetal lambs during late or prolonged gestation. J Physiol 275:567579, 1978.

25. Eguchi K, Yonezawa M, Mitsui Y, Hiramatsu Y. Developmental changes of glutamate dehydrogenase activity in rat liver mitochondria and its enhancement by branched-chain amino acids. Biol Neonate 62(2-3):83-38, 1992. 